\title{
16S rDNA-Based Identification of Novel Superoxide Dismutase Producing Bacteria Isolated from Indonesia
}

\author{
ANA INDRAYATI ${ }^{1}$, VALENTINA YURINA ${ }^{2}$, \\ LARAS AJENG PITAYU ${ }^{2}$, AND DEBBIE SOEFIE RETNONINGRUM²* \\ ${ }^{1}$ University of Galuh, Jalan RE Martadinata 150, Ciamis 46251, Indonesia; \\ ${ }^{2}$ School of Pharmacy, Institut Teknologi Bandung, Jalan Ganesha 10, Bandung 40132, Indonesia
}

\begin{abstract}
Superoxide dismutase (SOD) has therapeutic importance because of its antioxidant activity and protects cells from reactive oxygen species attack. This research was intended to screen bacteria isolated from Indonesia for producing novel SODs and to identify the producers using $16 \mathrm{~S}$ rDNA approach. Intracellular proteins were each extracted and assayed for their inhibition reduction activity by colorimetric method and by zymography for the presence of SOD protein band(s). For species identification, each of $16 \mathrm{~S}$ rDNA genes was amplified by polymerase chain reaction from genomic DNA followed by sequencing, BLAST, multiple alignment and phylogenetic analyses. All 16 intracellular proteins gave inhibition reduction percentage in the range of 15 to $70 \%$ and in zymography, their SOD profiles were quite diversed with at least one intense SOD band present in most isolates. The SOD producers were assigned to three species, Flavobacterium okeanokoites, Escherichia fergunosii, and E. coli and to four genera, Pantoea, Escherichia, Bacillus, and Pectobacterium. The remaining five were grouped in gamma-proteobacterium cluster and two formed a cluster with Pseudomonas. Three marine and four soil isolates could be attractive candidates for novel SODs based on unique properties of SOD producers. In conclusion, 16s rDNA-based identification of bacteria isolated from Indonesia reveals that seven isolates might be attractive candidates for novel SOD producers to be applied in pharmaceutical fields in the future.
\end{abstract}

Key words: 16S rDNA, superoxide dismutase, zymography, marine bacteria, soil bacteria

Superoksida dismutase (SOD) penting untuk terapi karena aktivitas antioksidannya dan sel dilindungi dari radikal oksigen species. Penelitian ini bertujuan melakukan penapisan terhadap isolat bakteri dari Indonesia yang menghasilkan SOD baru dan melakukan identifikasi spesies bakteri dengan pendekatan 16S rDNA. Protein intrasel diisolasi dan diuji aktivitas penurunan inhibisinya secara kolorimetri dan dianalisis dengan zimografi untuk mendeteksi keberadaan protein SOD. Untuk identifikasi spesies, setiap gen 16S rDNA diamplifikasi dengan polymerase chain reaction dari DNA genom, dilanjutkan dengan analisis urutan nukleotida, BLAST, pensejajaran urutan nukleotida, dan pembuatan pohon filogenetika. Sebanyak 16 protein intrasel memberikan inhibisi reduksi antara 15 dan $70 \%$ dan dengan zimografi, profil SOD-nya cukup beragam dengan setidaknya satu pita tebal SOD pada sebagian besar isolat. Penghasil SOD diidentifikasi sebagai tiga spesies, yaitu Flavobacterium okeanokoites, Escherichia fergunosii dan E. coli dan empat genus, yaitu Pantoea, Escherichia, Bacillus, dan Pectobacterium. Lima isolat dimasukkan dalam kelompok gamma-proteobakteri, sedangkan dua isolat ke dalam kelompok Pseudomonas. Tiga isolat dari laut dan empat isolat dari tanah berpotensi sebagai kandidat penghasil SOD baru berdasarkan pada keunikan SOD yang dihasilkan. Identifikasi berbasis 16S rDNA bakteri dari Indonesia menunjukkan ada tujuh isolat kandidat yang menarik sebagai penghasil SOD baru yang dapat diterapkan di bidang farmasi di masa depan.

Kata kunci: 16S rDNA, superoksida dismutase, zimografi, bakteri laut, bakteri tanah

Superoxide dismutases (SODs) [E.C. 1.15.1.1] are key enzymes that play a role in protecting cells and tissues from toxic effects of free radicals (Pan et al. 1999). They catalyze the conversion of toxic superoxide radical $\left(\mathrm{O}_{2}-\right)$ to less toxic hydrogen peroxide $\left(\mathrm{H}_{2} \mathrm{O}_{2}\right)$ and oxygen $\left(\mathrm{O}_{2}\right)$ (McCord and Fridovich 1969). A number of aerobic bacteria and Archaea has been reported to produce SODs. As many as 57 SOD homolog genes were found in 138 bacterial and archaeal genomes (Banci et al. 2005). SODs from prokaryotes require metal ions as cofactors and based on their cofactors, SOD from prokaryotes are classified as $(\mathrm{Cu}, \mathrm{Zn}) \mathrm{SOD}, \mathrm{Fe}-\mathrm{SOD}, \mathrm{Mn}-\mathrm{SOD}$, and Ni-SOD (Wuerges et al. 2004). Several bacterial SODs have been thoroughly investigated and SODs from

*Corresponding author, Phone/Fax: + 62- 22- 2504852, Email: retnoningrum@indo.net.id psychrophilic, mesophilic, and thermophilic bacteria have also been reported (Valderas et al. 2001; Castellano et al. 2006; He et al. 2007).

SODs have been used in pharmaceutical field in particular for therapeutic and cosmetic purposes. It was reported that SOD is useful as therapeutic agent for treatment of inflammatory disorders (Yasui and Baba 2006). Another work indicated that the inclusion of SOD in combination with catalase in cosmetic preparations prevents skin aging (Lods et al. 2000). Some reports demonstrated that decrease of SOD gene expression is associated with apoptosis and a number of neurodegenerative diseases including Parkinson's disease and Alzheimer (Choi et al. 2005; Nikam et al. 2009).

Our laboratory is interested in finding novel SODs for therapeutic and cosmetic applications. Due to high microbial diversity, Indonesia has potential to contain 
SOD-producers from previously unidentified microorganisms. The number of prokaryotes on earth was predicted to be $4-6 \times 10^{30}$ and only minority of them has been explored for SOD activity (Curtis et al.2004).

Our current work focused on the exploration of novel SOD-producing bacteria isolated from soil and marine sources in Indonesia. Our preliminary screening using a qualitative assay indicated that 16 of 40 bacterial isolates from our collection demonstrated SOD activity measured in a qualitative assay. In present research, we intended to measure the SOD activity from the 16 isolates in a more accurate quantitative assay, to confirm the presence of SOD protein using zymography and to identify SOD producers using $16 \mathrm{~S}$ rDNA-based method.

\section{MATERIALS AND METHODS}

Bacteria and Growth Media. All isolates were obtained from our culture collection and previously isolated from marine and soil sources in Indonesia. STLA, BL6, SCK, and SCK2 were isolated from sea water located at Cilaut Eureun, Garut, West Java; MKS11 and MKS13 were isolated from sea water close to Makassar, Sulawesi; others were isolated from soil at North Bandung, West Java. When first isolated, microbes from sea water were enriched in sea water broth then isolated using sea water agar. Microbes from soil were enriched in liquid nutrient medium and isolated using nutrient agar. Luria Bertani (LB) broth was used to grow all isolates in SOD measurement assay except nutrient broth was used for isolates STLA, $\mathrm{Cm} 2$, and MKS11.

Total Protein Preparation. 7.5\% (v/v) overnight culture grown in $37{ }^{\circ} \mathrm{C}$ was added to fresh liquid LB medium or nutrient broth and incubation was continued until the optical density of $580 \mathrm{~nm}$ of $0.4-0.6$ was reached. Bacterial suspension was centrifuged at $1600 \mathrm{~g}, 10^{\circ} \mathrm{C}$ for $10 \mathrm{~min}$; cell pellet was washed with phosphate buffer saline (PBS), resuspended in $1.5 \mathrm{~mL}$ of PBS and phenyl methyl sulphonyl fluoride was added until final concentration of $1 \mathrm{mM}$. Cells was lyzed using sonication (Fisher Sonic Dismembrator, Model, 300) at $4 \mathrm{MHz}$ on ice $30 \mathrm{sec}$ for each cycle, with $30 \mathrm{sec}$ break for each cycle, until the bacterial suspension opacity significantly reduced. After sonication, the lysate was centrifuged at $1400 \mathrm{~g}, 6^{\circ} \mathrm{C}$ for $10 \mathrm{~min}$. Total protein extract was concentrated using freeze-drying technique until half of original volume; the concentrated protein was analyzed for its SOD activity.

SOD Assay. Assay was done using colorimetric and zymography methods. In colorimetric assay, SOD activity was determined for its ability to inhibit nitro blue tetrazolium (NBT) reduction by riboflavin and tetramethylethylenediamine (TEMED), according to published method using $50 \mu \mathrm{L}$ extract protein (Sun et al. 1988). The presence of SOD activity in protein extracts was confirmed by zymography method as previously described using $3 \mu \mathrm{g}$ of intracellular proteins (Kim et al. 2000).

16S rDNA-Based Identification. The 16S rDNA of the 16 microbes were amplified by PCR using a pair of specific primers, UniBI (5'-GGTTAC (GC) TTGTTACGACTT-3') and BactF-I (5'AGAGTTTGATC(AC)TGGCTCAG-3') (Weisburg et al. 1991). The PCR products were analyzed using $1 \%$ agarose gel electrophoresis, purified from gel using GFX PCR DNA and Gel Band Purification Kit (Amersham) and directly sequenced using both primers by an automated DNA sequencer (Macrogen, Korea) to obtain complete nucleotide sequences of $16 \mathrm{~S}$ rDNA gene. The sequences were then analyzed for identity using NCBI BLAST (http://www. ncbi.nlm.nih.gov) and WU-BLAST program (http://www.ebi.ac.uk) to $16 \mathrm{~s}$ rDNA sequences of species deposited in NCBI and EMBL databases. Identification to species level was defined as sequence identity of minimum of $99 \%$ to sequences deposited in those databases; assignment at genus level was defined as sequence identity of $97-99 \%$ to sequences of previously characterized bacterial species. Microbial isolate could not be assigned to any taxa when similarity score lower than $97 \%$ with those present in the databases at the time of analysis (Harris and Hartley 2003; Janda and Abbott 2007). Interpretation of sequence data was valid only if a percentage of position ambiguity was less than $1 \%$. Multiple sequence alignment was done using clustalW2 to each isolate displaying similar percentage identity (http://www.ebi.ac.uk/Tools/msa/clustalw2/). Phylogenetic analysis was first performed to each isolate showing the similar percentage identity using ClustalW2-Phylogeny program based on neighborjoining clustering method to determine taxonomic relationships (http://www.ebi.ac.uk). The analysis was repeated to all isolates displaying percentage identity lower than $99 \%$ simultaneously after multiple alignments with $16 \mathrm{~s}$ rDNA sequences showing the closest taxonomic relationships obtained from individual phylogenetic analysis.

\section{RESULTS}

Bacterial Isolates Obtained from Indonesia. Our preliminary data showed that all 16 isolates displayed SOD activity in a qualitative assay. In current work, our semiquantitive assay showed that the reduction 
inhibition value was in the range of 14.95 to $70.42 \%$ confirming that all isolates produced SOD with variable degree (Table 1). However, the colorimetric assay has limitation because other substances besides SOD may interfere the value of $\%$ reduction inhibition. To rule out this possibility, zymography was performed to demonstrate the presence of protein band with SOD activity. Electrophoretic mobilities, the number and the intensity of SODs from each isolate seemed to be quite variable. Multiple SODs (more than 1 SOD bands) were observed in several isolates while others only produced one SOD (Fig 1, Table 1). With regards to their SOD protein band intensity, almost all isolates produced one intense SOD band but in some of them, one or two additional bands were also present. Three isolates only produced one intense SOD band, STLA, BL6 and BCD3. In general, the presence of intense SOD band agreed with high SOD activity measured by $\%$ reduction inhibition and vice versa (Table 1). However, some isolates contained weak SOD band in zymography gave high activity in colorimetric assay and several isolates contained at least one predominant SOD band showed low activity in the semiquantitative assay.

The Identification of Soil and Marine Isolates Producing SOD Activity. The size of 16s rDNA PCR products was approximately 1410 base pairs (bp) which agreed to its theoretical size (Fig 2). Results of
BLAST analysis of two-directions sequencing of $16 \mathrm{~s}$ rDNA gene combined with individual phylogenetic analysis for percentage identity and microbial assignment are depicted in Table 1. Based on the criteria for taxa assignment (see Materials and Methods), three bacteria were identified to species level, STLA to Planomicrobium okeanokoites (renamed as Flavobacterium okeanokoites) and Staphylococcus equorum, BBK to Escherichia fergusonii, and TKC to E. coli. Another four isolates were only assigned to genus level, TW to Escherichia, Sku2 to Pantoea, MKS 13 to Bacillus, and VR1 to Pectobacterium. However, the remaining seven isolates exhibited lower sequence similarity in the range of $85-94 \%$ and two isolates gave more than $1 \%$ nucleotide ambiguity; therefore, they could not be further analyzed.

Phylogenetic analysis to 11 unidentified isolates demonstrated that they were grouped into four clusters (Fig 3). Two marine isolates, MKS 13 and Sc2, formed a cluster with Bacillus subtilis and B. mucilaginosus. VR and Sku2 isolated from soil were positioned in one group with soil bacteria, Pectobacterium carotovorum and Pantoea vagans. BCD, a soil bacterium and BL6, a marine isolate were clustered in one group of Pseudomonas fluorescens and Pseudomonas sp. Three soil isolates (BDG1, Cm4, and TW) and one marine bacterium (MKS11) were grouped with gammaproteobacteria.

Table 1 SOD activity of 16 microbial samples determined by semiquantitative method based on 16s rDNA-based approach

\begin{tabular}{|c|c|c|c|c|c|}
\hline $\begin{array}{l}\text { Name of } \\
\text { isolates }\end{array}$ & Taxon assignment and percentage identity & $\begin{array}{l}\text { Microbial } \\
\text { sources }\end{array}$ & $\begin{array}{l}\text { Reduction } \\
\text { inhibition (\%) }\end{array}$ & SOD band & Band intensity \\
\hline STLA & $\begin{array}{l}\text { Planomicrobium okeanokoites } \\
\text { Staphylococcus equorum }(99 \%)\end{array}$ & Marine & 66.81 & 1 & Intense \\
\hline BBK & Escherichia fergusonii (99\%) & Soil & 28.74 & $\begin{array}{l}1 \\
2\end{array}$ & $\begin{array}{l}\text { Intense } \\
\text { Weak }\end{array}$ \\
\hline B16 & Pseudomonas sp. IGCAR-26/07 (82\%) & Marine & 70.42 & 1 & Intense \\
\hline $\mathrm{Cm} 2$ & NA* & Soil & 40.74 & 1 & Weak \\
\hline SCK & $\mathrm{NA}^{*}$ & Marine & 47.06 & $\begin{array}{l}1 \\
2\end{array}$ & $\begin{array}{l}\text { Intense } \\
\text { Weak }\end{array}$ \\
\hline BDG 2 & Erwinia pyrifolia $(85 \%)$ & Soil & 51.52 & $\begin{array}{l}1 \\
2\end{array}$ & $\begin{array}{l}\text { Intense } \\
\text { Weak }\end{array}$ \\
\hline $\mathrm{BCD}$ & Pseudomonas fluorescens (90\%) & Soil & 62.87 & 1 & Intense \\
\hline BDG & Gamma-proteobacterium (90\%) & Soil & 36.54 & 2 & Weak \\
\hline TW & Escherichia coli $(98 \%)$ & Soil & 61.90 & 1 & Weak \\
\hline VR & Pectobacterium carotovorum (97\%) & Soil & 14.95 & $\begin{array}{l}1 \\
2\end{array}$ & $\begin{array}{l}\text { Intense } \\
\text { Weak }\end{array}$ \\
\hline $\mathrm{Sc} 2$ & Bacillus mucilaginosus (95\%) & Marine & 25.81 & 4 & Weak \\
\hline Sku2 & Pantoea vagans C9-1 (98\%) & Soil & 36.36 & $\begin{array}{l}3 \\
2\end{array}$ & $\begin{array}{l}\text { Intense } \\
\text { Weak }\end{array}$ \\
\hline TKC & Escherichia coli $(99 \%)$ & Soil & 33.33 & 2 & Intense \\
\hline MKS 11 & Shigella sp. $(92 \%)$ & Marine & 37.50 & 1 & Weak \\
\hline MKS 13 & Bacillus subtilis $(98 \%)$ & Marine & 39.29 & $\begin{array}{l}2 \\
1\end{array}$ & $\begin{array}{l}\text { Intense } \\
\text { Weak }\end{array}$ \\
\hline $\mathrm{Cm} 4$ & Shigella flexneri $(94 \%)$ & Soil & 62.96 & $\begin{array}{l}1 \\
1\end{array}$ & $\begin{array}{l}\text { Intense } \\
\text { Weak }\end{array}$ \\
\hline
\end{tabular}

*Percentage of ambiguity $>1 \%$ 


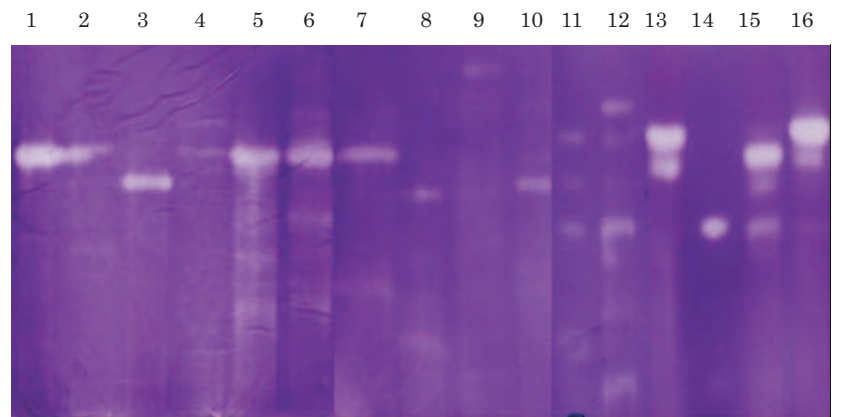

Fig 1 SOD activity of bacterial intracellular total proteins from mid-log phase determined by zymography. 1, STLA; 2, BBK; 3, BL6; 4, Cm2; 5, SCK; 6, BDG2; 7, BCD3; 8, BDG1; 9, TW; 10, VR; 11, Sc2; 12, Sku2; 13, TKC; 14, MKS11; 15, MKS13; and 16, $\mathrm{Cm} 4$. Isolates STLA, BBK, and TKC were identified as Planomicrobium okeanokoites, Escherichia fergusonii, and E. coli, respectively.

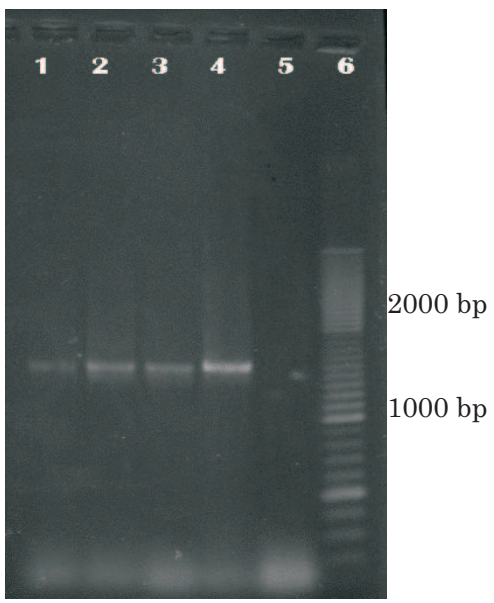

Fig 2 Representative of 16S rDNA gene SOD-producing isolates. Lanes 1-4, isolates BCD, VR, TW, and STLA, respectively; 5, negative control; 6, 100 bp DNAmarker.

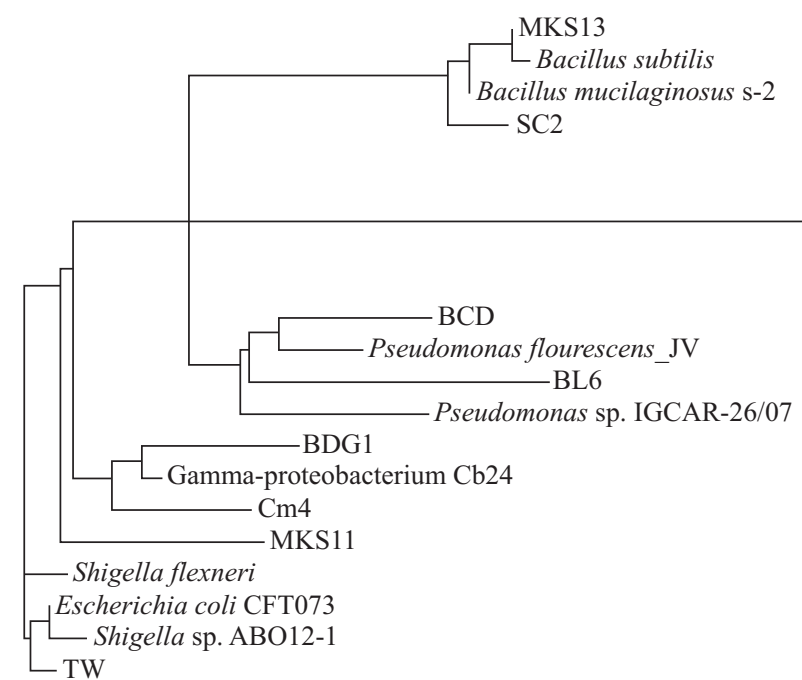

\section{DISCUSSION}

Our result showed the SOD profiles were quite variable in all isolates and this phenomenon agrees with that of other investigations (Yun and Lee 2002). In general, the SOD activity measured by percentage inhibition reduction agreed with the results from zymography. However, several protein preparations showed disagreement between the two results. The total proteins may contain other substances that lowered the percentage reduction inhibition or on the other hand, SOD inhibitors may be present in the protein preparations resulting high percentage reduction inhibition.

Our 16S rDNA gene sequencing provided genus identification only $43.7 \%$ and even less for species assignment, $18.7 \%$. This result was in contrast with other studies where 16S rDNA-based analysis yielded better species and genus identification rates of 62 to $91 \%$ and $88.7 \%$, respectively (Janda and Abbott 2007). In the present work, $56.3 \%$ of isolates remained unidentified and the number was significantly higher than previously reported, 1 to $14 \%$ (Janda and Abbott 2007). A previous work indicated that a different rate of higher than $0.5 \%$ could be used a consideration for assignment of a new species within a known genus (Drancourt et al. 2000). Therefore, based on this concern, 11 isolates discovered in this study may be novel species under certain genera. Other housekeeping genes such as $s o d \mathrm{~A}$ or $r p o \mathrm{~B}$ should be used for species identification in future experiment.

Based on BLAST analysis (Table 1) and phylogenetic analysis of individual isolate (data not

Fig 3 Neighbor-joining tree based on 16s rDNA sequences analysis. Eleven isolates are clustered into four groups, two with bacilli, two with Pseudomonas, two with Pantoea and Pectobacterium, and the remaining are in gamma-proteobacterium groups. 
shown), STLA exhibited $99 \%$ identity to two species, $S$. equorum and F. okeanokoites. S. equorum is present in human and certain animal skin and also reported to be isolated from processed food. On the other hand, F. okeanokoites was reported to be present in marine sediment and grew well in the presence of 0 $7 \%$ of $\mathrm{NaCl}$ (Dai et al. 2005). It is a Gram variable depending on the presence of $\mathrm{NaCl}$ in the growth medium (Nakagawa et al. 1996). In our Gram staining, STLA was a Gram negative bacterium and since it was isolated from marine sediment; therefore, it was assigned as F. okeanokoites.

Since the temperature used for microbial growth was $37{ }^{\circ} \mathrm{C}$, it was not surprising that all isolates identified belonged to mesophilic microbes. Our isolate, TKC and BBK identified as E. coli and $E$. fergunosii, respectively were isolated from soil and later grown at $37^{\circ} \mathrm{C}$. It has been known that they are distributed in water and soil. All other 11 isolates were also taxonomically close to mesophilic bacteria. Since we are interested in SODs to be applied for human use, the SODs from mesophilic bacteria is suitable considering that they are stable at human temperature, $37^{\circ} \mathrm{C}$.

Except for E. coli, SODs from species identified in current work have not been studied extensively (Gregory et al. 1973; Steinman et al. 1994). Particularly interesting are SODs from marine bacteria since they might have unique properties. F. okeanokoites was reported to grow well in the presence of $0-7 \%$ of $\mathrm{NaCl}$ (Nakagawa et al. 1996); hence STLA might be a source of novel salt resistant SOD. The information of SOD from $F$. okeanokoites was currently unavailable; however, our zymography demonstrated that STLA produced one major SOD (Fig 1, lane 1). B. subtilis grows between $25-35{ }^{\circ} \mathrm{C}$ and its main habitat is soil; however, most bacilli isolated from marine origin were $B$. subtilis. A marine isolate of $B$. subtilis was demonstrated to resist high temperature $\left(50-55^{\circ} \mathrm{C}\right)$ and high $\mathrm{NaCl}(10 \%)$ and it can grow at broad range of pHs, 5.7 - 11.5 (Ivanova et al. 1999). Our isolate, MKS 13, has a potency to produce unique SOD since it was obtained from marine source and its taxonomy is close to $B$. subtilis. Three sod genes were found in genome of $B$. subtilis subsp. subtilis strain 168. In our zymography experiment, MKS13 was shown to produce three SOD proteins with one major SOD band, probably due to the response to aerobic condition in our experiment. SODs from marine bacilli have not been investigated and therefore, MKS13 is an attractive bacterium for producing novel SODs.
Four isolates, BDG1, Cm4, MKS11 and TW were grouped in gamma-proteobacterium (Fig 3). The amino acid sequences of SODs of the members of this group share high homology to those of E. coli; therefore, they are not attractive candidate for further study. Two isolates, BL6 and BCD were clustered with Pseudomonas sp. and P. fluorosence (Fig 3). In Pseudomonas, only SOD from $P$. aeruginosa has been studied. Therefore, both bacteria especially BL6, a marine isolate might produce SODs with novel properties. Isolates Sku2 and VR were assigned in the genera of Pantoea and Pectobacterium, respectively and SODs from both genera have not been explored.

\section{ACKNOWLEDGEMENTS}

This research was funded by Science and Technology Research Grant 2007 from Indonesia Toray Science Foundation to Ana Indrayati.

\section{REFERENCES}

Banci L, Bertini I, Calderone V, Cramaro F, Conte RD, Fantoni A, Mangani S, Quattrone A, Viezzoli MS. 2005. A prokaryotic superoxide dismutase paralog lacking two $\mathrm{Cu}$ ligands: from largely unstructured in solution to ordered in the crystal. PNAS. 102(21):75417546. doi: 10.1073/pnas. 0502450102 .

Castellano I, Di Maro A, Ruocco MR, Chambery A, Parente A, Di Martino MT, Parlato G, Masullo M, De Vendittis E. 2006, Psychrophilic superoxide dismutase from Pseudoalteromonas haloplanktis: biochemical characterization and identification of a highly reactive cysteine residue. Biochimie. 88(10):1377-1389. doi:10.1016/j. biochi.2006.04.005.

Choi J., H. D. Rees Weintraub, A. I. Levey, L. S. Chin, and L. Li, 2005, Oxidative modifications and aggregation of $\mathrm{Cu}, \mathrm{Zn}$-superoxide dismutase associated with alzheimer and Parkinson diseases. Biochem. 280(12):11648-11655. doi:10.1074/jbc.M414327200.

Dai X, Wang YN, Wang BJ, Liu SJ, Zhou YG. 2005. Planomicrobium chinense sp. nov., isolated from coastal sediment, and transfer of Planococcus psychrophilus and Planococcus alkanoclasticus to Planomicrobium as Planomicrobium psychrophilum comb. nov. and Planomicrobium alkanoclasticum comb. nov. Int J Sys Evol Microbiol. 55(2):699-702. doi:10.1099/ijs.0.63340-0.

Drancourt M, Bollet C, Carlioz A, Martelin R, Gayral JP, Raoult D. 2000. 16S Ribosomal DNA sequence analysis of a large collection of environmental and clinical unidentifiable bacterial isolates. J Clin Microbiol. 38(10):3623-3630.

Gregory EM, Yost FJ, Fridovich I. 1973. Superoxide dismutases of Escherichia coli: intracellular localization and functions. J Bacteriol. 115(3):987-991.

Harris KA, Hartley JC. 2003. Development of broad-range 16S rDNA PCR for use in the routine diagnostic clinical microbiology service. J Med Microbiol. 52(8):685691. doi:10.1099/jmm.0.05213-0.

He YZ, Fan KQ, Jia CJ, Wang ZJ, Pan WB, Huang L, Yang KQ, Dong ZY. 2007. Characterization of a hyperthermostable Fe-superoxide dismutase from hot spring. Appl Microbiol Biotechnol. 75(2):367-376. doi:10.1007/s00253-006-0834-3

Ivanova EP, Vysotskii MV, Svetashev VI, Nedashkovskaya OI, Gorshkova NM, Mikhailov VV, Yumoto N, Shigeri Y, Taguchi T, Yoshikawa S. 1999. Characterization of Bacillus strains of marine origin. Internatl Microbiol. 2(4):267-271. 
Janda JM, Abbott SL. 2007. 16S rRNA gene sequencing for bacterial identification in the diagnostic laboratory: pluses, perils, and pitfalls. J Clin Microbiol. 45(9):2761-2764. doi: 10.1128/JCM.01228-07.

Kim TS, Jung Y, Na BK, Kim KS, Chung PR. 2000. Molecular cloning and expression of $\mathrm{Cu} / \mathrm{Zn}$-containing superoxide dismutase from Faschiola hepatica. Infect Immun. 68(7):3941-3948.

Lods LM, Dres C, Johnson C, Scholz DB, Brooks GJ. 2000. The future of enzymes in cosmetics. Intern J Cosmetic Sci. 22(2):85-94. doi:10.1046/j.1467-2494.

McCord JM, Fridovich I. 1969. Superoxide dismutase: an enzymic function for erythrocuprein (hemocuprein). J Biol Chem. 244(22):6049-6055. doi:10.1016/S0014-4835(80)80026.

Nakagawa N, Sakane T, Yokota A. 1996. Emendation of the genus Planococcus and transfer of Flavobacterium okeanokoites Zobell and Upham 1944 to the genus Planococcus as Planococcus okeanokoites comb. nov. Int J Syst Bacteriol. 46(4):866-870. doi: 10.1099/ 00207713-46-4-866.

Nikam S, Nikam P, Ahaley SK, Sontakke AV. 2009. Oxidative stress in Parkinson's disease. Int J Clin Biochem. 24(1):98-101.

Pan SM, Hwang GR, Liu HC. 1999. Over-expression and characterization of copper/zinc-superoxide dismutase from rice in Escherichia coli. Bot BullAcad Sin. 40:275-281.
Steinman HM, Weinstein L, Brenowitz M. 1994. The manganese superoxide dismutase of Escherichia coli K-12 associates with DNA. J Biol Chem. 269(46):28629-28634.

Sun Y, Oberley LW, Li Y. 1988. A simple method for clinical assay of superoxide dismutase. Clin Chem. 34(3):497-500.

Valderas MW, Hart ME. 2001. Identification and characterization of a second superoxide dismutase gene (sodM) from Staphylococcus aureus. J Bacteriol. 183(11):3399-3407. doi:10.1128/JB.183.11.33993407.

Weisburg WG, Barns SM, Pelletier DA, Lane DJ. 1991. 16S Ribosomal DNA amplification for phylogenetic study. J Bacteriol. 173(2):697703.

Wuerges J, Lee JW, Yim YI, Yim HS, Kang SO, Carugo KD. 2004. Crystal structure of nickel-containing superoxide dismutase reveals another type of active site. PNAS. 101(23):8569-8574. doi:10.1073/pnas. 0308514101.

Yasui K, Baba A. 2006. Therapeutic potential of superoxide dismutase (SOD) for resolution of inflammation. Inflamm Res. 55(9) 359-363. doi:10.1007/s00011-006-5195-y.

Yun YS, Lee YN. 2002. Production of superoxide dismutase by Deinococcus radiophilus, J Biochem Mol Biol. 36(3):282-287. 